\title{
THE HERPETOLOGY OF CAJA DE MUERTOS ISLAND AND CARDONA KEY, PORTO RICO
}

\author{
Chapman Gran's, Major, United States Amyy \\ and Corneluts Roosevetr
}

'The interesting little Island of Caja de Muertos, Coffin Island, 8 miles off Ponce, Porto Rico, has been nearly ignored by herpetologists. It is not mentioned by Stejneger, 1904, in his "Ilerpetology of Porto Rico", or by Barbour, 1930, in his "A List of Antillean Reptiles and Amphibians". Schmidt, 1928, Vol. X, Part 1, "Scientific Survey of Porto Rico and the Virgin Islands" mentions Anolis cristatellus, Ameiva wetmorei and Alsophis portoricensis as the only forms known from the Island.

On July 26th, 1931, the joint writers visited the Island and secured the following 53 specimens, adding 3 species to the fauma, bringing the total to 6 species:

Anolis cristatellus, 21; very numerous and apparently not differing in habits or form from the mainland specimens.

Anolis pulchellus, 3; not abundant, but apparently not differing in form or coloring from the mainland specimens.

Ameiva exsul, 6; not abundant, seemingly the dorso-lateral stripes persist longer than in the mainland specimens.

Ameina wetmorei eleanorae, 6; not abundant; described in this maper.

Sphatrodactylus tounsendi, 17 ; not rare, differ slightly from the Vieques and Porto Rican specimens.

On August 20, 1931, we received a small collection comprising Anolis pulchellus, 3; Sphacrodactylus townsendi, 4; Typhlops jamaiconsis sp. ?, 2; Alsophis portoricensis, 3 ; and Phyllodactylus tuboreulosus. 1. adding 3 species to the famna, bringing the total to 9 species.

On November 26, 1931, the senior writer again visited Caja de Muertos and captured 38 specimens:

Sphatrodactylus townsendi, Phyllodactylus tubereulosus, Anolis pulchellus, Anotis cristatellus.

$\begin{array}{rlr}5 ; & \text { Amciva retmorei cleanorae, } & 14 ; \\ 1 ; & \text { Ameina exsul, } & 3 ; \\ 1 ; & \text { Typhlops jamaicensis, sp.?, } & 2 ; \\ 11 ; & \text { Alsophtis portoricensis } & 1 .\end{array}$

The Alsophis do not resemble the series of eight A. portoricensis in the Grant collection, but resemble the series of thirty $A$. antillensis in the same collection, in color and pattern but not in squamation. 
The Typhlops appears to be distinct.

Barbour mentions Phyllodactylus spatulatus Cope; "Barbados collected years ago, about 1861, in fact, by Dr. Theodore Gill. I have no recent information as to its status". This is the nearest record of this genus to the present locality. The present find adds a genus to the Porto Rico fauna and a species to the Antilles.

On November 26, 1931, the senior writer visited Cardona Kev, a tiny sand-coral islet bearing a light-house, off the harbor of Ponee. Ameiva exsul fairly swarms and Anolis cristatellus is numerous. Nine Ameiva exsul and three Anolis cristatellus were taken. Exsul exhibited a wide range of color and pattern, but no turquoise blue tails or red or salmon undersides were seen. Some specimens had light brown unmarked backs, others had two complete white lines below the dorso-lateral line along the sides, formed by the coalescence of white dots. Critatellus showed no markings and a plain olive fan.

Ameiva wetmorei eleanorae subsp. nov.

There are 135 specimens of $A$. wetmorei in the Grant collection from the neighborhood of Cabo Rojo, P. R. There is little variation in this series. The white stripes are narrow and there is a faint brown stripe between the mid-dorsal stripe and the continuation of the subocular white stripe. This brown stripe is the eontinuation of the subocular white stripe.

Type No. 2734, Grant Collection, July 26, 1931, Caja de Muertos Island, Porto Rico. Collectors, Roosevelt and Grant.

Diagnosis: Differs from A. wetmor $i$ in having wider dorso-lateral white stripes. The supraocular white stripes usually stop at the base of neck instead of continuing on to tail as a brown stripe.

Habitat: Caja de Muertos Island, Porto Rico.

Proportions and squamation: As in A. wetmorei.

Color and pattern: The mid dorsal white line turns blue as it passes the sacrum. In the Muertos form this wide blue stripe includes an uneven, broken central black line from near the sacrum. In the Porto Rican form if the central black line occurs at all, it is much further down the tail. The supraocular white line usually stops at the neck in the Muertos form, leaving a jet black space between the middorsal white line and the continuation of the subocular white line. In the rare cases where this line continues in the Muertos form, it is merely as a faint white line. In the Porto Rican form, the supraocular white line turns brown at the shoulders and continues onto the tail. In the Muertos form the lowest white- 
line which runs from, armpit to groin is as clear eut and distinct as those above it. In the Porto Rico form, the lowest white line is blurred or wider than the ones above it. The Muertos form has a much tidier clear cut pattern with more contrast.

WIOTH IN SCALES OF MIDDORSAL WIITE LINE AT:

\begin{tabular}{|c|c|c|c|c|c|c|}
\hline \multirow[b]{2}{*}{ 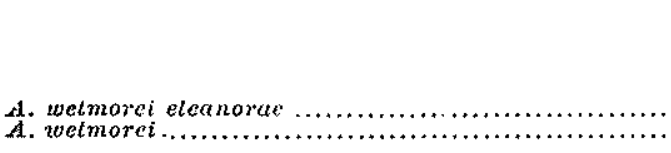 } & \multicolumn{2}{|c|}{ scapttlar } & \multicolumn{2}{|c|}{ miàbody } & \multicolumn{2}{|c|}{ sacral } \\
\hline & $\stackrel{1: 1 ! n}{2}$ & $\underset{3}{\max _{3}}$ & $\min _{\substack{3 \\
3 \\
1 / 2}}$ & $\underset{3}{\ln } \ln _{3}^{1 / 9}$ & $\min _{\substack{31 \\
31 \\
21}}$ & $\begin{array}{c}\max \\
5 \\
4\end{array}$ \\
\hline
\end{tabular}

AVERAGES OF THE ABOVE:

\begin{tabular}{|c|c|c|c|}
\hline & seapular & midbody & sacral \\
\hline $\begin{array}{l}\text { A. loetmorei eleunorat } \\
\text { Avetmorein } \\
\text { difference } \ldots\end{array}$ & $\begin{array}{r}2.5 \\
1.9 \\
.6\end{array}$ & $\begin{array}{l}3.2 \\
2.2 \\
1.0\end{array}$ & $\begin{array}{r}4.1 \\
3.3 \\
.8\end{array}$ \\
\hline
\end{tabular}

Remarks: Specimens taken 20. Named in honor of the junior writer's Mother, Eleanor Roosevelt.

The habits of this species are mentioned by the senior writer in "Copeia", July, 1931. 